\title{
The Transition from Yeast-like to Chlamydospore Cells in Pullularia pullulans
}

\author{
By J. B. DOMINGUEZ, F. M. GOÑI AND F. URUBURU \\ Departamentos de Biología y Bioquímica, Facultad de Ciencias, Apartado 644, \\ Bilbao, Spain
}

(Received 27 February 1978)

The transition from yeast-like to chlamydospore cells was induced by growing Pullularia pullulans on an unbuffered glucose medium with a limiting nitrogen source. The kinetics of cell growth and extracellular polymer prcduction were determined. Changes in cell morphology were apparent during the whole process. Yeast-like cells became progressively enlarged before producing chlamydospores. The proportion of sugars increased at the expense of proteins and nucleic acids during the transition. Quantitative and qualitative changes in phospholipids were observed. Fatty acid unsaturation decreased as the cells grew older. Enzymic cell-wall analysis also revealed differences in the wall structures of the different forms. Protoplasts were easily prepared from yeast-like cells, but could not be produced from other cell forms.

\section{INTRODUCTION}

The polymorphic fungus Pullularia pullulans (de Bary) Berk. has attracted increasing attention in recent years because of its wide distribution and industrial applications (Merdinger, 1969). It has a complex life-cycle involving yeast-like cells, filaments, chlamydospores and intermediate forms (Wynne \& Gott, 1956; Ramos \& García-Acha, 1975; Brown et al., 1973). In a previous paper from our laboratory, the influence of nutrients and other factors on the morphology of $P$. pullulans has been reported (Sevilla et al., 1977).

In the strain under study, chlamydospores can be obtained either from the filamentous phase or directly from the yeast-like cells, by means of nutritional control (Brown et al., 1973). The present paper describes the kinetic and nutritional aspects of the transformation from yeast-like to chlamydospore cells, as well as the changes in chemical composition accompanying the morphogenetic transition.

\section{METHODS}

Organism. A strain of Pullularia pullulans isolated and identified in our laboratory (Sevilla et al., 1977) was used. This strain is no. 2660 of the Colección Española de Cultivos Tipo (CECT). The organism was maintained on basal mineral medium slants containing $(\%, w / v): \mathrm{KH}_{2} \mathrm{PO}_{4}, 0 \cdot 05 ; \mathrm{K}_{2} \mathrm{HPO}_{4}, 0 \cdot 2 ; \mathrm{MgSO}_{4} .7 \mathrm{H}_{2} \mathrm{O}, 0.05$; $\mathrm{FeSO}_{4} .7 \mathrm{H}_{2} \mathrm{O}, 0 \cdot 001 ;$ glucose, $1 ;\left(\mathrm{NH}_{4}\right)_{2} \mathrm{SO}_{4}, 0 \cdot 15 ;$ agar, $1 \cdot 2$.

Inoculum and culture conditions. Inocula were obtained from $24 \mathrm{~h}$-old cells grown on agar slants at $28{ }^{\circ} \mathrm{C}$. The cells were harvested with sterile distilled water and the culture media were inoculated to give a final concentration of $0.01 \mathrm{mg}$ dry wt organisms $\mathrm{ml}^{-1}$. This inoculum contained only yeast-like cells. Cultures were usually grown in $250 \mathrm{ml}$ flasks containing $50 \mathrm{ml}$ medium, and incubated at $28{ }^{\circ} \mathrm{C}$ in a rotary shaker (200 rev. min $^{-1}$ ). The culture medium was similar to the maintenance medium, except that agar was omitted and glucose was increased to $10 \%(\mathrm{w} / \mathrm{v})$.

Observation and measurement of growth. Microscopic observations were made using a C-35 standard RA Zeiss microscope, equipped with phase contrast. A variety of techniques were used to assess culture growth. 
Cell counts were made with a Burker-type haemocytometer and by plate counting. Dry weights were measured as described by Hunter \& Rose (1972), after filtration through Millipore filters (GSWP 04700; pore width $0.22 \mu \mathrm{m})$ or after centrifugation $(2000 \mathrm{~g}$ for $10 \mathrm{~min}$ ) followed by two washes with distilled water. Population size was estimated turbidimetrically at $535 \mathrm{~nm}$ using a Spectronic 20 Bausch and Lomb spectrophotometer.

Chemical analysis. Free glucose was measured by the glucose oxidase method (Bergmeyer, 1965); total sugars were estimated by the anthrone method (Chung \& Nickerson, 1954); extracellular polymer was measured according to Catley (1971). Ammonia consumption was measured according to Solórzano (1969). Protein was estimated by the method of Lowry et al. (1951) with bovine serum albumin as standard. Nucleic acids were determined spectrophotometrically, according to Chaykin (1966). Lipids were extracted and determined microgravimetrically by the method of Hunter \& Rose (1972) as slightly modified by Goñi \& Macarulla (1977). Lipid phosphorus was determined according to Bartlett (1959). Phospholipids were separated by thin-layer chromatography according to Neskovic \& Kostic (1968) and quantified as lipid phosphorus. Phospholipid classes were identified with the aid of standards and specific reagents (Goñi \& Macarulla, 1977). The amount of neutral lipids was calculated from the experimental data for total lipids and phospholipids. Fatty acids were analysed as their methyl esters by gas-liquid chromatography, according to López-Moratalla et al. (1973). The degree of unsaturation for a given sample was calculated from the percentage distribution of fatty acids as $1(\%$ monoenes $)+2(\%$ dienes $)+3(\%$ trienes $)$; the degree of unsaturation expressed in this way then relates to the number of double bonds per 100 fatty-acid molecules.

Cell-wall analysis and preparation of protoplasts. Lytic broths were obtained from Micromonospora chalcea AS (CECT 3195) (Gascón \& Villanueva, 1964), Basidiomycete QM806 (CECT 2722) (Reese \& Mandels, 1959), Streptomyces venezuelae RA (CECT 3069) (Rodriguez-Aguirre et al., 1963) and Streptomyces flavovirens FL (CECT 3208) (García-López et al., 1973). The Basidiomycete broth was used as a crude preparation of $(1-3)-\beta$-glucanase. Chitinase, $\alpha$ - and $\beta$-amylase and protease were purchased from Sigma. Cell walls were prepared according to Dominguez (1977).

In the enzymic digestions, $5 \mathrm{mg}$ walls or $10 \mathrm{mg}$ cells were treated with 25 i.u. of each enzyme in a total volume of $5 \mathrm{ml} 0.03 \mathrm{M}$-phosphate buffer, $\mathrm{pH} \mathrm{7.2}$. For the preparation of protoplasts, $2 \mathrm{mg}$ cells and the corresponding amount of lytic broth were made up to $5 \mathrm{ml}$ with phosphate buffer and osmctically stabilized with $\mathrm{MgSO}_{4}, \mathrm{KCl}$, mannitol or sorbitol, in concentrations ranging from 0.5 to $1.0 \mathrm{M}$. The mixture was incubated at $30^{\circ} \mathrm{C}$ with gentle rotation and the process was followed by phase-contrast microscopy.

\section{RESULTS}

\section{Growth and morphology}

Growth of Pullularia pullulans under the conditions described in Methods was accompanied by a series of morphogenetic changes. The present study was limited to $14 \mathrm{~d}$ culture, although some processes were known to continue for a longer period.

The increase in cell number in the culture followed a simple pattern in which the stationary phase was reached after $72 \mathrm{~h}$ (Fig. $1 \mathrm{~b}$ ). However, dry weight determinations and extracellular polymer measurements revealed the existence of more complex processes (Fig. 1a). Dry weights measured after centrifugation were different from those measured after filtration. This was because the extracellular polymer was retained by the Millipore filter but was not present in the washed centrifuged cells, as indicated by direct measurements of the polymer (Fig. 1a). The term 'biomass' will be used for measurements made on the preparation after filtration, unless otherwise specified.

The increase in biomass showed a close correlation with the decrease in glucose in the medium (Fig. 2a). Glucose was present initially in large amounts, and much of this had not been consumed after $14 \mathrm{~d}$ culture. Ammonia, however, was completely consumed by the end of the exponential phase, and this process was accompanied by a marked decrease in pH (Fig. 2).

From the above data, a number of representative points were chosen in order to study the morphological and chemical variations at various stages of the transition process. These points were $1,2,3,6,10$ and $14 \mathrm{~d}$ after the start of culture growth.

Changes in cell morphology were apparent during the whole period. Figure 3 shows some of the morphological variations accompanying the changes observed by kinetic measure- 


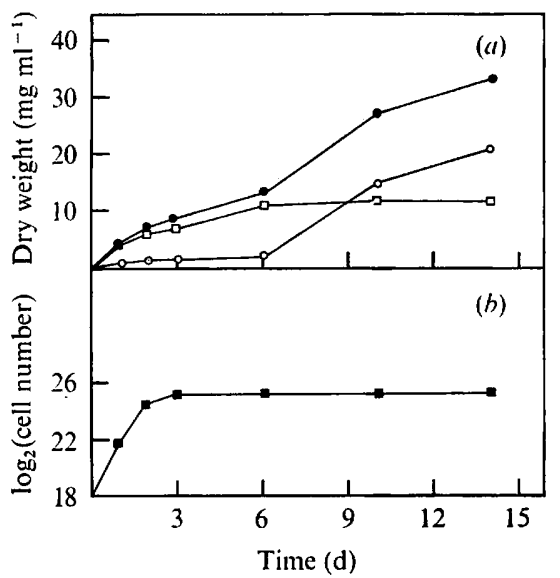

Fig. 1

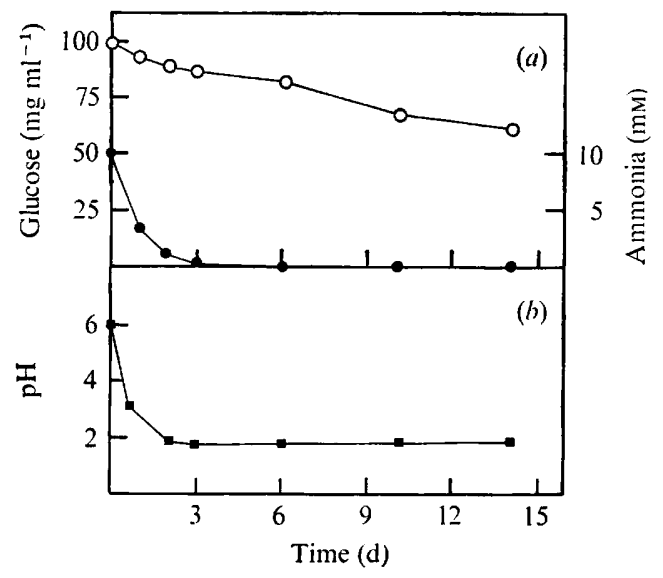

Fig. 2

Fig. 1. Growth kinetics of $P$. pullulans: $\bullet$, dry weight after filtration, 'biomass'; $\square$, dry weight after centrifugation; $O$, dry weight of polymer; $\mathbf{0}, \log _{2}$ (cell number).

Fig. 2. Variation of glucose concentration $(\bigcirc)$, ammonia concentration $(\bullet)$ and $\mathrm{pH}(\boldsymbol{v})$ in the medium.
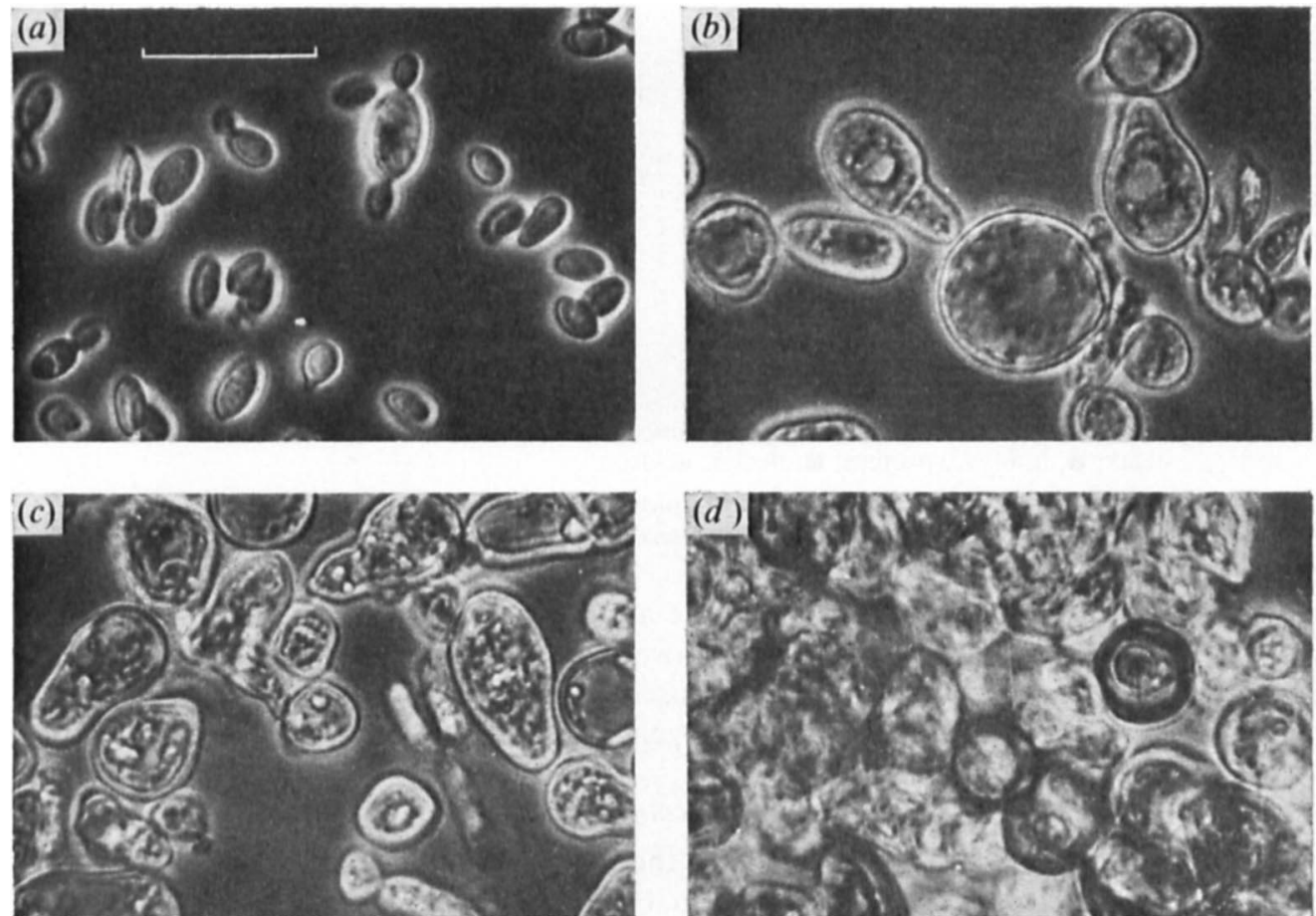

Fig. 3. Morphology of cells of $P$. pullulans grown for $(a) 1 \mathrm{~d},(b) 3 \mathrm{~d},(c) 6 \mathrm{~d}$ and $(d) 14 \mathrm{~d}$. Bar marker represents $10 \mu \mathrm{m}$.

ments. The cells had a yeast-like appearance during the exponential phase of growth, and increased in size towards the third day. From the third to the sixth day the walls became progressively enlarged, which, together with the increase in polymer production, accounts for the concomitant increase in biomass. Chlamydospores appeared from the sixth day on, 
Table 1. Distribution of lipid phosphorus in the various phospholipid classes during the morphogenetic transition

Phospholipid class

Lysoderivatives Phosphatidylserine Sphyngomyelin Phosphatidylinositol Phosphatidylcholine Phosphatidylethanolamine Cardiolipin

Phosphatidyl- $N$ methylethanolamine

Lipid phosphorus (mol \%)* after growth for:

\begin{tabular}{|c|c|c|c|c|c|}
\hline $1 \mathrm{~d}$ & $2 \mathrm{~d}$ & $3 d$ & $6 \mathrm{~d}$ & $10 \mathrm{~d}$ & $14 \mathrm{~d}$ \\
\hline $2 \cdot 5 \pm 0 \cdot 29$ & $4 \cdot 3 \pm 1 \cdot 55$ & $3 \cdot 3 \pm 0 \cdot 72$ & $4 \cdot 4 \pm 0 \cdot 87$ & $4 \cdot 8 \pm 0 \cdot 77$ & $6 \cdot 1 \pm 0 \cdot 44$ \\
\hline $15 \cdot 0 \pm 1 \cdot 15$ & $9 \cdot 4 \pm$ & $10 \cdot 0 \pm 1 \cdot 06$ & $17 \cdot 4 \pm 1 \cdot 24$ & $11 \cdot 7 \pm 1 \cdot 00$ & $22 \cdot 2 \pm 1 \cdot 27$ \\
\hline $4 \cdot 2 \pm$ & $4.6 \pm 0.58$ & $4.0 \pm 0.63$ & $3 \cdot 1 \pm 0.33$ & $4.6 \pm 0.60$ & $10 \cdot 6 \pm 0.95$ \\
\hline $10 \cdot 8 \pm 1 \cdot 35$ & $9 \cdot 0 \pm 0.44$ & $7 \cdot 2 \pm 0.62$ & $8 \cdot 8 \pm 1 \cdot 00$ & $7 \cdot 3 \pm 0 \cdot 66$ & $9 \cdot 2 \pm 1 \cdot 37$ \\
\hline $29 \cdot 6 \pm 1.41$ & $26.9 \pm 3.97$ & $26 \cdot 2 \pm 2 \cdot 32$ & $25 \cdot 0 \pm 3 \cdot 35$ & $30 \cdot 0 \pm 2 \cdot 61$ & $23 \cdot 4 \pm 1 \cdot 86$ \\
\hline $15 \cdot 5 \pm 1 \cdot 60$ & $13 \cdot 1 \pm 0 \cdot 84$ & $12 \cdot 0 \pm 1 \cdot 26$ & $17 \cdot 7 \pm 0.83$ & $16 \cdot 7 \pm 1 \cdot 51$ & $15 \cdot 1 \pm 1 \cdot 55$ \\
\hline $11 \cdot 0 \pm 0.82$ & $21 \cdot 8 \pm 1 \cdot 11$ & $22 \cdot 4 \pm 1 \cdot 55$ & $17 \cdot 3 \pm 0.83$ & $8 \cdot 6 \pm 0 \cdot 84$ & $8 \cdot 8 \pm 1 \cdot 16$ \\
\hline $11 \cdot 6 \pm 1 \cdot 01$ & $10.9 \pm 0.83$ & $14.5 \pm 0.94$ & $7 \cdot 0 \pm 0.66$ & $16 \cdot 5 \pm 1 \cdot 32$ & $4.5 \pm 0.68$ \\
\hline
\end{tabular}

* Figures represent mean values \pm S.E.M. of at least four experiments.

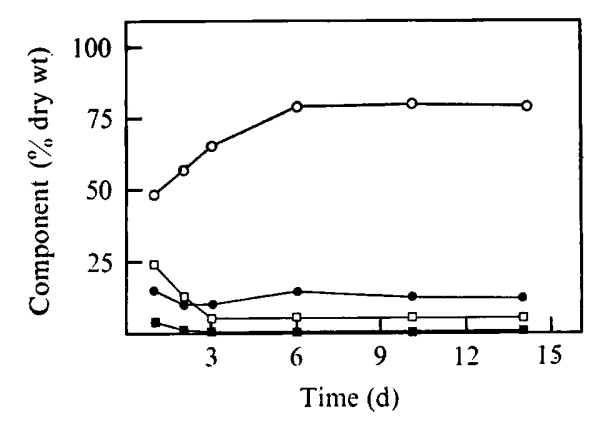

Fig. 4

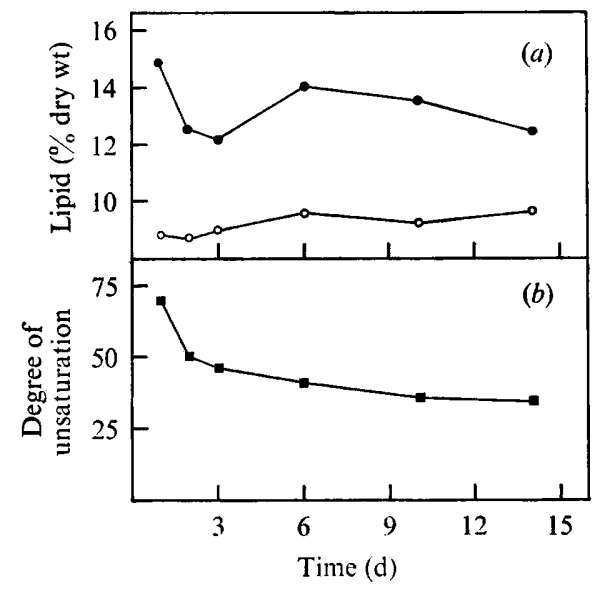

Fig. 5

Fig. 4. Variation in percentage chemical composition of $P$. pullulans during morphogenetic transition: $\bigcirc$, sugar; $\bullet$, lipid; $\square$, protein; $\square$, nucleic acids.

Fig. 5. Variation in the percentages of neutral lipids $(\bullet)$ and phospholipids $(O)$, and in the total degree of fatty acid unsaturation ( $\square$ ) of $P$. pullulans during morphogenetic transition.

and their proportion increased as the culture aged. Simultaneously, the culture became a greenish-brown colour. Typical chlamydospores were spherical, and their cytoplasm was homogeneous under the phase-contrast microscope, in contrast to the younger cells, which contained cytoplasmic granules of a birefringent character.

\section{Chemical components}

When the overall chemical composition of the cells was studied throughout the morphogenetic process, a decrease was observed in the relative amounts of biologically active proteins and nucleic acids (Fig. 4), together with a marked increase in carbohydrate content. No significant variation was observed in the proportion of lipid.

The variation in lipid composition was studied in some detail. The amount of phospholipids, expressed as a percentage of the dry weight, showed a slight variation with time (Fig. $5 a$ ), whereas the neutral lipids showed a decrease during the exponential phase, followed by an increase from the third to the sixth day, and a subsequent decrease associated with the transition from large cells to chlamydospores. Although the overall proportion of phospho- 
Table 2. Maximum degree of hydrolysis after enzyme treatment of 1,3 and $10 \mathrm{~d}$-old cells and cell walls

\begin{tabular}{lrrrrrr} 
& \multicolumn{5}{c}{ Percentage of dry weight hydrolysed } \\
Enzyme & Cells & Cells & Cells & Walls & Walls & Walls \\
Glucanase & $1 \mathrm{~d}$ & $3 \mathrm{~d}$ & $10 \mathrm{~d}$ & $1 \mathrm{~d}$ & $3 \mathrm{~d}$ & $10 \mathrm{~d}$ \\
Chitinase & 12.0 & 43.5 & 54.5 & 27.5 & 26.5 & $50 \cdot 0$ \\
Amylases & $2 \cdot 0$ & 0.0 & 0.0 & 2.0 & 0.0 & 0.0 \\
Protease & 7.0 & $8 \cdot 5$ & 5.5 & 8.5 & 8.5 & 12.5 \\
& 0.0 & 0.0 & 0.0 & 0.0 & 0.0 & 0.0
\end{tabular}

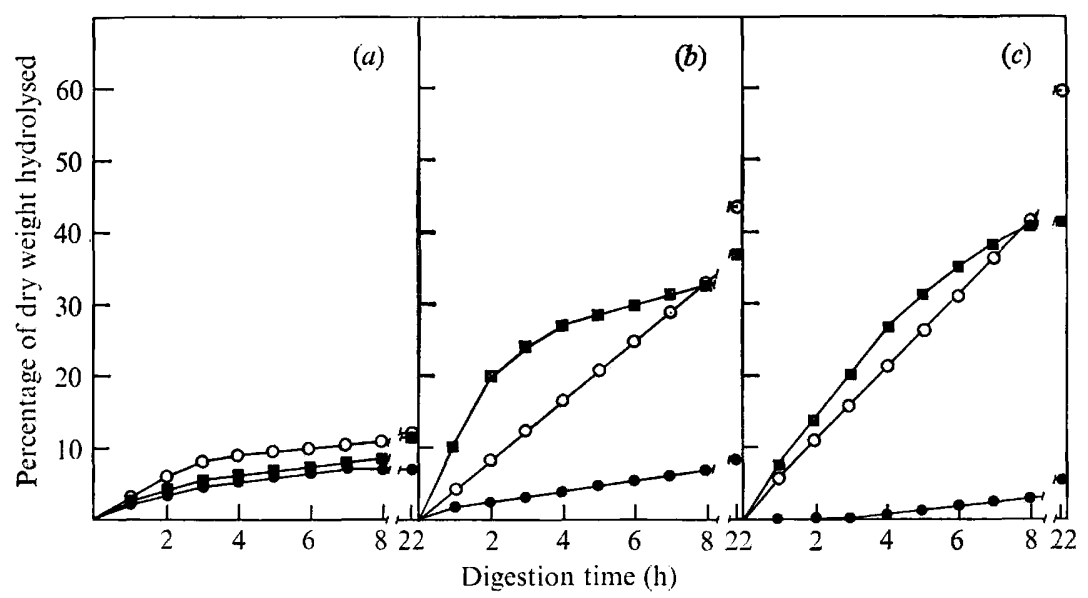

Fig. 6. Enzymic hydrolysis of cells of $P$. pullulans grown for $(a) 1 \mathrm{~d},(b) 3 \mathrm{~d}$ and $(c) 10 \mathrm{~d}$ : $\bigcirc$, glucanase; $\mathbf{0}$, amylases; $\mathbf{\varphi}$, glucanase plus amylases.

lipids did not change with time, the proportions of some phospholipid classes showed considerable variation (Table 1). In the first $10 \mathrm{~d}$, the main variation was in cardiolipin, which increased from day 1 to 3 , and then decreased. The opposite was true for phosphatidylserine and phosphatidylethanolamine. The proportion of phosphatidyl- $N$-methylethanolamine also underwent considerable changes, especially after the third day. The major change in phospholipid composition, which concerned mainly phosphatidylserine, sphyngomyelin and phosphatidyl- $N$-methylethanolamine, took place between days 10 and 14 , i.e. during the period of maximum chlamydospore formation.

The degree of fatty acid unsaturation of the total cell lipid decreased very rapidly during the exponential phase; thereafter there was a slow, steady decline during the remainder of the experiment (Fig. $5 b$ ).

\section{Cell-wall analysis and protoplast formation}

The comparative hydrolytic effect of several enzymes on the cell walls was studied in intact cells and purified walls, prepared 1, 3 and $10 \mathrm{~d}$ after the onset of growth. The enzymes were used either pure or in combination. When used pure (Table 2), protease showed no activity with any preparation. When used in combination (data not shown), its effect was to decrease the activity of the other enzymes in the mixture, possibly because of proteolytic attack on those enzymes. Chitinase activity was low with walls from 1-d-old cells, and undetectable in all the other preparations. No synergistic effect was observed when chitinase was used in combination with other enzymes. As expected from previous chemical data (Brown et al., 1973), $(1 \rightarrow 3)$ - $\beta$-glucanase was very active in hydrolysing cell walls. A mixture 
of $\alpha$-and $\beta$-amylases was also effective to some extent, the activity probably being against extracellular pullulan, in view of the structural similarities between this polysaccharide and starch. It is interesting to note the synergistic effect of the $(1 \rightarrow 3)$ - $\beta$-glucanase and amylases in the first $8 \mathrm{~h}$ incubation with 3 - and 10-d-old cells (Fig. $6 b, c$ ). This effect would be consistent with the existence of an extracellular capsule of starch-like pullulan covering the wall in these cells. With longer incubation times $(24 \mathrm{~h})$, this synergistic effect was not seen, perhaps because of substrate competition effects (Fig. 6).

One-d-old cells gave rise to protoplasts when treated with Micromonospora chalcea lytic broth as described by Ramos \& García-Acha (1975). Protoplasts were also obtained in good yields ( 90 to $95 \%$ after $4 \mathrm{~h}$ ) with the lytic broth of Streptomyces venezuelae. In these two cases the lytic effect took place preferentially at the equatorial region of the cell. The Streptomyces flavovirens broth, with a predominant chitinase activity, attacked the apical region preferentially. The Basidiomycetes broth, rich in $(1 \rightarrow 3)-\beta$-glucanase, uniformly attacked the whole cell surface, giving rise to sphaeroplasts rather than to protoplasts.

With $3 \mathrm{~d}$ and older cells, we were unable to obtain any intact protoplasts, even with the most scrupulous precautions against osmotic lysis, probably because of the mechanical fragility of these protoplasts.

\section{DISCUSSION}

The induction of the different forms of the vegetative cycle in fungi can be achieved by controlling nutritional factors (Bartnicki-García, 1968). One example of morphogenetic induction by nutritional control is the transition from yeast-like cells to chlamydospores in $P$. pullulans. In most strains, chlamydospores are produced from the filamentous phase. However, Brown et al. (1973) have described the direct production of chlamydospores from yeast-like cells, and this seems to be the case in the strain we have studied. According to our observations, yeast-like cells give rise, towards the end of the exponential phase, to the so-called 'large cells' (Sevilla et al., 1977) which, after a certain time, prcduce free chlamydospores.

Chemical analysis of chlamydospores and of yeast-like cells showed significant variations in the proportions of cell components. An increasing amount of carbohydrate accompanied the ageing of the culture. Simultaneously, the relative quantities of biologically active polymers decreased. Thus, the active cells were progressively being transformed into a resistant form.

The total lipid content of the different forms was always between 10 and $15 \%$. This is in accord with the studies of Merdinger \& Cwiakala (1968), and places $P$. pullulans among the 'medium lipid content' yeasts (Rattray et al., 1975). The phospholipid content was relatively low, since it varied from 1.5 to $3.4 \%$ dry weight, and most yeast species have a phospholipid content of 3.0 to $7.0 \%$ (Letters, 1968). The decrease in unsaturated fatty acids could represent an adaptive response of the cell towards the decreasing external $\mathrm{pH}$ value, since membrane permeability in general parallels fatty acid unsaturation (Henry \& Keith, 1971).

The polysaccharides of yeast-like and chlamydospore cell walls of $P$. pullulans have been studied previously (Brown \& Lindberg, 1967a, b; Brown et al., 1973). Our data, obtained from enzymic analysis, are in accord with the earlier methylation analysis. The overall results suggest that the walls have an outer layer of $(1 \rightarrow 4)-\alpha,(1 \rightarrow 6)-\alpha$-glucan (pullulan) and and inner layer of $(1 \rightarrow 3)$ - $\beta$-glucan. This inner layer would become larger as the cells grew older. Chlamydospore walls would contain an additional component not present in yeastlike cell walls, namely a melanin-like material, located, according to (unpublished) electron microscope observations, in the outermost wall layer.

The authors are grateful to Professor M. Richmond and Dr L. Egea for their critical reading of the manuscript, and to Miss A. Pujana for her secretarial assistance. 


\section{REFERENCES}

Bartlett, G. R. (1959). Phosphorus assay in column chromatography. Journal of Biological Chemistry 234, 466-468.

BARTNICKI-GARCÍA, S. (1968). Cell-wall chemistry, morphogenesis and taxonomy of fungi. Annual Review of Microbiology 22, 87-105.

Bergmeyer, H. U. (1965). Methods of Enzymatic Analysis. Berlin: Springer Verlag Chemie.

Brown, R. G. \& LindberG, B. (1967a). Polysaccharides from cell walls of Aureobasidium (Pullularia) pullulans. I. Glucans. Acta chemica scandinavica 21, 2373-2382.

Brown, R. G. \& Lindberg, B. (1967b). Polysaccharides from cell walls of Aureobasidum (Pullularia) pullulans. II. Heteropolysaccharide. Acta chemica scandinavica 21, 2383-2389.

Brown, R. G., Hanic, L. A. \& Hsiao, M. (1973). Structure and chemical composition of yeast chlamydospores of Aureobasidium pullulans. Canadian Journal of Microbiology 19, 163-168.

Catley, B. J. (1971). Role of $\mathrm{pH}$ and nitrogen limitation in the elaboration of the extracellular polysaccharide pullulan by Pullularia pullulans. Applied Microbiology 22, 650-654.

ChAykin, C. (1966). Biochemistry Laboratory Techniques. New York: John Wiley.

Chung, C. W. \& Nickerson, W. J. (1954). Polysaccharide synthesis in growing yeasts. Journal of Biological Chemistry 208, 395-407.

Dominguez, J. B. (1977). Morphogenetic studies in Pullularia pullulans. Ph.D. thesis, University of Bilbao.

García-López, M. D., Laborda, E., Uruburu, F. \& Villanueva, J. R. (1973). Identification of a lytic microorganism isolated from the soil as a strain of Streptomyces flavovirens. Japanese Journal of Microbiology 17, 223-227.

Gascón, S. \& VillanueVa, J. R. (1964). Extracellular lytic enzymes of Micromonospora. Canadian Journal of Microbiology 10, 301-303.

Goñı, F. M. \& Macarulla, J. M. (1977). Métedos de analisis de lípidos. Laboratorio 64, 501-519.

Henry, S. A. \& Keith, A. D. (1971). Membrane properties of saturated fatty acid mutants of yeast revealed by spin labels. Chemistry and Physics of Lipids 7, 245-265.

HuNTER, K. \& Rose, A. H. (1972). Lipid composition of Saccharomyces cerevisiae as influenced by growth temperature. Biochimica et biophysica acta 264, 606-618.
LetTers, R. (1968). Phospholipids of yeasts. In Aspects of Yeast Metabolism, pp. 303-319. Edited by A. K. Mills. Oxford: Blackwells Scientific Publications.

López-Moratalla, N., Pérez, P., Eugui, J. \& Santiago, E. (1973). Phospholipids of outer mitochondrial membranes. Effect of ascorbate on their polyunsaturated fatty acids. Revista española de fisiología 29, 41-46.

Lowry, O. H., Rosebrough, N. J., Farr, A. L. \& RaNDall, R. J. (1951). Protein measurement with the Folin phenol reagent. Journal of Biological Chemistry 193, 265-275.

Merdinger, E. (1969). Uptake of glucose-1-14C by Pullularia phllulans. Journal of Bacteriology $\mathbf{9 8}$, 1021-1025.

Merdinger, E. \& Cwiakala, C. E. (1968). Fatty acids of the lipids from Pullularia pullulans. Lipids 2, 276-277.

Neskovic, N. M. \& Kostic, D. M. (1968). Quantitative analysis of rat liver phospholipids by a two-step thin-layer chromatographic procedure. Journal of Chromatography 35, 297-300.

Ramos, S. \& García-AchA, I. (1975). A vegetative cycle of Pullularia pullulans. Transactions of the British Mycological Society 64, 129-135.

Rattray, J. B. M., Schibeci, A. \& Kidby, D. K. (1975). Lipids of yeasts. Bacteriological Reviews 39, 197-231.

Reese, E. T. \& Mandels, M. (1959). $\beta$-D(1-3)glucanases in fungi. Canadian Journal of Microbiology 5, 173-185.

Rodriguez-Aguirre, M. J., García-ACha, I. \& VillanueVA, J. R. (1963). An enzyme from a Streptomyces $\mathrm{sp}$, to prepare mould 'protoplasts'. Experientia 19, 82.

Sevilla, M. J., Isusi, P., Gutierrez, R., Egea, L. \& URUBURU, F. (1977). Influence of carbon and nitrogen sources in the morphogenetic change of a strain of Pullularia pullulans. Transactions of the British Mycological Society 68, 300-303.

Solórzano, L. (1969). Determination of ammonia in natural waters by phenolhypochlorite methods. Limnology and Oceanography 14, 799-801.

WyNNe, E.S. \& GotT, C. L. (1956). A proposed revision of the genus Pullularia. Journal of General Microbiology 14, 512-519. 